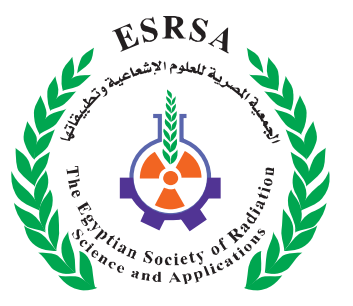

J. Nucl. Tech. Appl. Sci., Vol. 6, No. 1, PP. 1 : 12 (2018)

\title{
In Vitro Study to Recognize the Optimum Conditions Affecting the Endophytic Cellulase Production
}

El-Gamal, M.S. ${ }^{1}$; El-Ghandour, I.A. ${ }^{2}$; Abdel-Aziz, O.A. ${ }^{2}$; Mousa, A.M. ${ }^{2}$; Radwan, A.A. ${ }^{1}$ and Abdel-Moghies, A.H. ${ }^{2}$

Received: 28/11/2017

Accepted: 30/01/2018

E.mail:Moghies.eaea_1@yahoo.com

\section{KEYWORDS}

Cellulase Enzyme,

Endophytic

Cellulolytic Bacteria,

Culture Conditions.

\section{ABSTRACT}

In this study traditional microbiological isolation techniques were used to recognize cellulolytic activity of most potent isolates. The isolates were identified using both morphological and molecular methods. Functional studies were carried out to determine the optimum $\mathrm{pH}$, temperature, incubation period, inoculum size, carbon and nitrogen sources for screened isolate. High cellulase producing endophytic bacteria Achromobacter spanius, Bacillus amyloliquefaciens and Stenotrophomonas maltophilia isolated from leaves, stems and roots of; Clover, Wheat, Lettuce, Spinach, Vicia Faba, Garlic, Dill, Olive, Acacia and Prosopis trees were subjected to controlled conditions in laboratory. Tested factors which believed to be effective on improving growth conditions were studied in vitro to achieve the highest production of cellulase enzyme. The highest values of cellulase were produced by Achromobacter spanius $(2.50 \mathrm{mg} / \mathrm{ml})$ followed by Bacillus amyloliquefaciens $(2.26 \mathrm{mg} / \mathrm{ml})$ after 6 days of incubation. The optimum conditions resulted in optimum cellulase production were $30^{\circ} \mathrm{C}$ at $\mathrm{pH} 6$ for Achromobacter and Bacillus while the optimum conditions for Stenotrophomonas was $40^{\circ} \mathrm{C}$ at $\mathrm{pH} 7$. Isolates produced the highest values of cellulase with ammonium sulphate and $30 \mathrm{~g} / \mathrm{l}$ glucose as nitrogen and carbon sources, respectively. Achromobacter was more effective in producing cellulase than Bacillus and Stenotrophomonas. This was true under all the tested conditions.

1. Department of Microbiology, Faculty of Science, Al-Azhar University, Cairo, Egypt.

2. Soil and Water Research Department, Nuclear Research Center, Atomic Energy Authority, Cairo, Egypt. 


\section{INTRODUCTION}

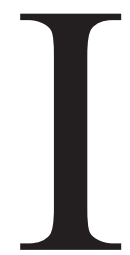

$\mathrm{n}$ vitro series of microbiological tests were carried out to recognize the most effective aseptic conditions that improved the efficiency of endophytic bacteria in producing cellulose enzyme. Lignocellulosic biomass is the most abundant organic material in nature with high biotechnological potential (Rastogi et al., 2010). The large volume of lignocellulolytic waste could cause serious environmental pollution (Vivek et al., 2008). The cellulose conversion to simple sugars by microorganisms plays an important role in the carbon cycle (Romano et al., 2013). A set of cellulases such as endoglucanase (1, 4-ß-D-glucan4-glucanohydrolase; EC 3.2.1.4), exocellobiohydrolase (1, 4-ß-D-glucan-gluco-hydrolase; EC3.2.1.74) and $ß$-glucosidase ( $ß$-D-glucoside-gluco-hydrolase; EC3.2.1.21) is required for complete hydrolysis of cellulosic material. Lastly, the cellobiose is converted to glucose by ß-glucosidase (Lynd et al., 2002). Some bacterial genera such as Bacillus and Paenibacillus are capable of degrading both Carboxymethyl cellulose (CMC) and Avicel (carbon source) (Afzal et al., 2010), as well as lignocellulosic waste from the agro-industry (Macedo et al., 2013). Low cost agricultural residues such as sugarcane bagasse, wheat bran, rice bran and others, which have been found to be good sources of cellulase production moreover; various carbon sources in the growth medium influenced the bacterium's ability to produce cellulose (Techapun et al., 2003).

Cellulose, a crystalline polymer of D-glucose residues connected by $\beta-1,4$ glucosidic linkages, being the primary structural material of plant cell wall, is the most abundant carbohydrate in nature (Saha et al., 2006). Therefore, it has become considerable economic interest to develop processes for effective treatment and utilization of cellulosic wastes as inexpensive carbon sources. Cellulose enzyme is responsible of cellulose degradation and produced by several microorganisms, commonly by bacteria and fungi. Immanuel el al., (2006) explored that Cellulomonas, Bacillus and Micrococcus spp. were more effective in producing endoglucanase enzyme at $\mathrm{pH}$ ranged from 5-7. Microorganisms are important in conversion of lignocellulose wastes into valuable products like biofuels produced by fermentation (Lynd et al., 2002). Consequently, successful bioconversion of cellulosic materials mainly depends on the nature of cellulose, sources of cellulolytic enzyme and optimal conditions for catalytic activity and production of enzymes (Alam et al., 2004).

In this respect, some studies have been focused on the cellulase producing fungi (Lan et al., 2013; Saini et al., 2015; Sharma et al., 2015; Callow et al., 2016), bacteria (Rastogi et al., 2010; Assareh et al., 2012; Shanmugapriya et al., 2012) and actinobacteria (Cirigliano et al., 2013; Sarita et al., 2013). Enormous amounts of agricultural, industrial and municipal cellulosic wastes are accumulating or used inefficiently due to their high cost towards utilization processes (Lee et al., 2008). Therefore, this problem is arising as a topic of considerable economic interest to develop processes for the effective treatment and utilization of cellulosic wastes as inexpensive carbon sources. Nandimath et al., (2016) found that, increasing glucose in addition to optimum $\mathrm{pH}$, temperature, time and nutritional requirements resulted in high cellulase production. Therefore, the present work aimed at recognizing the optimum conditions for improvement of enzymatic hydrolysis of organic residues specially rice straw to protect the environment from expected pollution.

\section{MATERIALS AND METHODS:}

\section{Sample Collection and Isolation of Endophytic Bacteria:}

Roots, stem and leaves of clover and wheat under clay soils from Sohag City -Egypt, lettuce, spinach, vicia faba, garlic, Acacia and Prosopis trees under sandy soils from Anshas -Elsharkia City- Egypt, Wheat, Dill and Olive under calcareous salt-affected 
soils from Ras Sudr - South Sinai City-Egypt, and Acacia and Prosopis trees from Desert Research Center in Mataria - Cairo City- Egypt, were transferred to the Lab. in sterile sampling bags and processed within 1 hour after collection. The plant organs were washed with running water to remove soil particles and were surface sterilized by sequential immersion in $70 \%$ ethanol for $5 \mathrm{~min}$ and solution of hypochlorite $(0.9 \%$ available chlorine) for $20 \mathrm{~min}$ utes, then washed three times with sterile distilled water to remove surface sterilizing agents before being soaked in $10 \% \mathrm{NaHCO}_{3}$ solution to disrupt the plant tissues and to inhibit the growth of fungi (Cao et al., 2003). Surface sterilized organ was divided into small fragments (1-3) cm under aseptic conditions and was placed on Luria Bertani agar media (LB-agar) used for isolation of endophytic bacteria (Gordon and Weber, 1951). This medium contains; tryptone $10 \mathrm{~g} / \mathrm{l}$, yeast extract $5 \mathrm{~g} / \mathrm{l}$, sodium chloride $5 \mathrm{~g} / \mathrm{l}$, agar $15 \mathrm{~g} / \mathrm{l})$. The LB-agar plates were incubated at $37^{\circ} \mathrm{C}$ for $2-3$ weeks.

Screening the endophytic cellulase producing bacteria:

\section{Qualitative assay}

Qualitative assay for cellulolytic activity of 58 bacterial isolates were processed using cellulose Congo red agar (CCA) contains (g/L): $\mathrm{K}_{2} \mathrm{HPO}_{4} 0.50$; $\mathrm{MgSO}_{4}$ 0.25; CMC 1.88; Gelatin 2.00; Congo red 0.20 ; trace salts solution $1.00 \mathrm{~mL}$. Trace salt solution was composed of, $\mathrm{FeSO}_{4} \cdot 7 \mathrm{H}_{2} \mathrm{O} 0.1 \mathrm{~g}, \mathrm{MnCl}_{2} \cdot 4 \mathrm{H}_{2} \mathrm{O}$ $0.1 \mathrm{~g}, \quad \mathrm{ZnSO}_{4} \cdot 7 \mathrm{H}_{2} \mathrm{O} 0.1 \mathrm{~g}$, distilled water 100.0 $\mathrm{ml}$ and agar $20.0 \mathrm{~g}$ as proposed by Hendricks et al., (1995). After sterilization, the clear opaque zone is measured using zone scale $3 \mathrm{~mm}$ in diameter. The plates were incubated at $37^{\circ} \mathrm{C}$ for five days. The plates were flooded with $1 \mathrm{M} \mathrm{NaCl}$ to detect the cellulolytic activity of isolates. The formation of a clear zone of hydrolysis indicated the CMC degradation. Clear zone diameter /colony diameter ratio was measured to select the highest cellulase producer (Ariffin et al., 2006).

\section{Quantitative assay}

The most efficient seventeen isolates elected after qualitative assay were subjected to quantitative assay. Quantitative screening of cellulase producing seventeen bacterial isolates was carried out using the modified medium after Hendricks et al. (1995), contains (g/L): $\mathrm{K}_{2} \mathrm{HPO}_{4}, 0.50 ; \mathrm{MgSO}_{4}, 0.25 ; \mathrm{CMC}$, 2.00; Trace salts solution, $1 \mathrm{~mL}$. $\mathrm{pH}$ of the medium was adjusted to 7.0 using $1 \mathrm{~N} \mathrm{NaOH}$ before autoclaving. About $10^{-3} \mathrm{CFU} / \mathrm{ml}$ of culture from the CCA slant was transferred to $250 \mathrm{~mL}$ Erlenmeyer flask containing $50 \mathrm{~mL}$ of cellulase production medium. The culture was incubated at $28 \pm 2^{\circ} \mathrm{C}$ with $200 \mathrm{rpm}$ for five days. The culture broth was centrifuged at $10,000 \mathrm{rpm}$ for $15 \mathrm{~min}$ at $4^{\circ} \mathrm{C}$ to separate the bacterial biomass. The cell free supernatant was analyzed for cellulase enzyme activity.

Identification of the most potent cellulase producing bacteria:

The most potent isolates were identified using 16S rRNA gene sequences to provide genus and species for isolates which processed by Sigma Scientific Services Co. The most potent isolates were identified as, Achromobacter spanius, Bacillus amyloliquefaciens, and Stenotrophomonas maltophilia.

\section{- DNA Extraction of Endophytic Bacteria:}

DNA extraction was carried out by using protocol of Gene Jet genomic DNA purification Kit, then PCR clean up to the PCR product was done using Gene JETTM PCR Purification Kit (Thermo K0701) according to Boom et al. (1990).

\section{- Phylogeny Tree Construction:}

Sequences of $16 \mathrm{~S}$ rRNA was matched with sequences of reference strains in GenBank database (http://www.ncbi.nlm.nih.gov) and was aligned through Clustal W Multiple Alignment tool. Phylogeny tree was constructed using phylogeny tool in MEGAV.6 program, inference using Maximum Likelihood method, and analyzed with evolutionary 
distance using Tamura-Nei model (Tamura et al., 2011).

\section{Bacterial strains:}

Endophytic bacteria Achromobacter spanius, Bacillus amyloliquefaciens and Stenotrophomonas maltophilia were maintained on carboxymethyl cellulose (CMC) broth media (Yin et al, 2010), ( $\mathrm{g} / \mathrm{l})$ : peptone 10.0; carboxymethyl cellulose (CMC) 10.0; $\mathrm{K}_{2} \mathrm{HPO}_{4} 2.0 ;\left(\mathrm{MgSO}_{4} .7 \mathrm{H}_{2} \mathrm{O}\right) 0.3 ;\left(\mathrm{NH}_{4}\right)_{2} \mathrm{SO}_{4} 2.5$ and gelatin 2.0; media is adjusted at $\mathrm{pH} 7$ for 5 days of incubation in shaker with $200 \mathrm{rpm}$ at $30^{\circ} \mathrm{C}$.

Optimum culture conditions for optimizing cellulase production:

The investigated parameters temperature, $\mathrm{pH}$, incubation periods, inoculum size, carbon sources and nitrogen sources affecting cellulase enzyme productivity were carried out on (CMC) broth media. Cellulase enzyme was determined in filtrates obtained from culture media according to Miller, (1959).

- Temperature, $p H$, incubation period, inoculum size, nitrogen source, Carbon source:

Carboxymethyl cellulose (CMC) broth media was used to determine the optimum temperature for cellulase production, at $\mathrm{pH} 7$ and inoculum size (10$\left.{ }^{3}\right)$ and various temperatures i.e. 30, 35, 40, 45, 50, 55 and $60^{\circ} \mathrm{C}$ and incubated for five days. Cell-free culture filtrate was obtained and used as enzyme source. Similar broth media were subjected to different $\mathrm{pH}$ $(5.0,5.5,6.0,6.5,7.0,7.5,8.5,8.5$ to 9.0$)$ for five days in flasks using $6 \mathrm{~N} \mathrm{HCl}$ or $6 \mathrm{~N} \mathrm{NaOH}$. The cultures were incubated at $30^{\circ} \mathrm{C}$. Different incubation periods and regular intervals of 2, 3, 4, 5, 6, and 7 days at $30^{\circ} \mathrm{C}$ were examined. Culture media was incubated under different incubation periods and regular intervals of $2,3,4,5,6$, and 7 days at $30^{\circ} \mathrm{C}$. The flasks inoculated with different inoculums size i.e. $\left(10^{-1}\right),\left(10^{-3}\right),\left(10^{-5}\right)$ and $\left(10^{-6}\right)$. Amm. sulphate, yeast extract and urea were used as $\mathrm{N}$ sources instead of peptone in (CMC) broth media. Glucose, soluble starch, insoluble starch, fructose, maltose, and sucrose) at different concentrations of 10,30 and $50 \mathrm{~g} / \mathrm{L}$ were examined in carboxymethyl cellulose (CMC) media instead of carboxymethyl cellulose.

\section{RESULTS AND DISCUSSION}

Screening of cellulolytic endophytic bacteria by qualitative assay:

About more than 58 microorganisms isolated, all microorganisms are able to grow on LB agar media but only some of them were able to produce clearing zone which indicated cellulolytic activity on CMC agar plates and proved positive to cellulolytic activity by cellulose-Congo red agar (CCA). About 17 isolates were active in producing clearing zone. Pure colonies of halo zone produced isolates were stored on slants.

Selection of the most potent cellulase productivity bacteria (quantitative assay):

17 isolates showed clear zone on cellulose Congo red agar media and exhibited remarkable enzyme activity were quantitatively screened for cellulolytic activity. Among them only Achromobacter spanius, Bacillus amyloliquefaciens, and Stenotrophomonas maltophilia were identified as the most potent isolates.

\section{Identification of the most potent cellulase produc- ing bacteria:}

Amplicon 16S rRNA sequences of isolates Achromobacter spanius, Bacillus amyloliquefaciens and Stenotrophomonas maltophilia was applied. On 1\% agarose gels showed in $1500 \mathrm{bp}$. Amplification 16S rRNA sequences of bacteria can produce 1500 - 1600 bp amplicon. Analysis of DNA sequences showed that isolates was identified as Achromobacter spanius (Fig. 1), Bacillus amyloliquefaciens (Fig. 2) and Stenotrophomonas maltophilia (Fig. 3).

Phylogeny Tree Construction: 


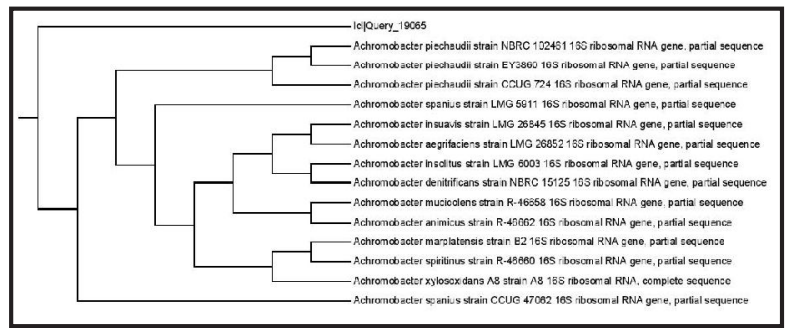

Fig. (1): Phylogeny tree of isolate No. (1) Was identified as Achromobacter spanius.

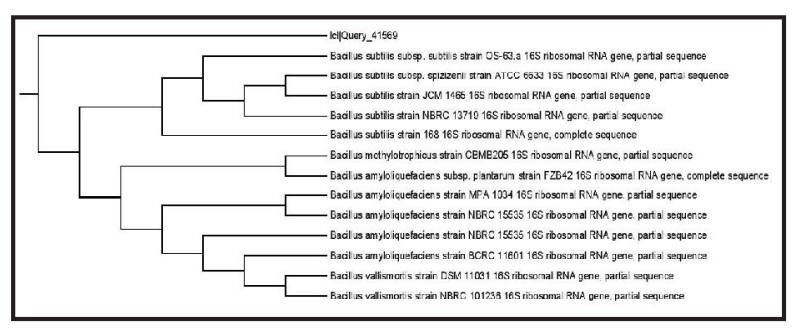

Fig. (2): Phylogeny tree of isolate No. (2) Was identified as Bacillus amyloliquefaciens.

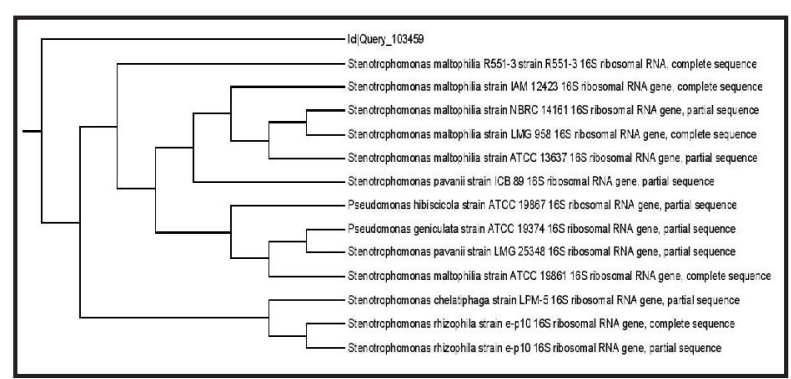

Fig. (3): Phylogeny tree of isolate No. (3) Was identified as Stenotrophomonas maltophilia.

\section{Optimization of cellulase production:}

The activity of enzyme excreted by Achromobacter spanius, Bacillus amyloliquefaciens, and Stenotrophomonas maltophilia. Under different investigated parameters were determined (Tables 1-6).

Table (1) : Effect of temperature on cellulase enzyme activity.

\begin{tabular}{|c|c|c|c|c|}
\hline \multirow{2}{*}{$\begin{array}{c}\text { Temperature } \\
{ }^{\circ} \mathbf{C}\end{array}$} & \multicolumn{4}{|c|}{ Enzyme activity Units (mg/ml) } \\
\cline { 2 - 5 } & Achromobacter spanius & $\begin{array}{c}\text { Bacillus } \\
\text { amyloliquefaciens }\end{array}$ & $\begin{array}{c}\text { Stenotrophomonas } \\
\text { maltophilia }\end{array}$ & Mean \\
\hline 30 & 1.38 & 1.34 & 0.89 & 1.20 \\
\hline 35 & 1.26 & 1.29 & 1.27 & 1.29 \\
\hline 40 & 1.21 & 1.17 & 1.30 & 1.23 \\
\hline 45 & 0.98 & 0.91 & 0.74 & 0.88 \\
\hline 50 & 0.96 & 0.90 & 0.61 & 0.82 \\
\hline 55 & 0.70 & 0.73 & 0.61 & 0.68 \\
\hline 60 & 0.59 & 0.65 & 0.60 & 0.61 \\
\hline Mean & 1.01 & 1.00 & 0.86 & \\
\hline
\end{tabular}

L.S.D. at 0.05: Bacteria 0.019, Temperatures, 0.030, Bacteria x Temperatures, 0.017 .

Gradual increase in incubation temperature resulted in decrease of cellulase production for Achromobacter and Bacillus respectively, while Stenotrophomonas reflected fluctuated response to different temperature affected cellulase production (Table.1). Cellulase activity of all isolates was decreased at $60^{\circ} \mathrm{C}$. The optimal temperature for growth was $30^{\circ} \mathrm{C}$ for Achromobacter spanius $(1.38 \mathrm{mg} / \mathrm{ml})$ and Bacillus amyloliquefaciens $(1.34 \mathrm{mg} / \mathrm{ml})$, recording the highest enzyme activity while Stenotrophomonas maltophilia produced the highest value of $1.30 \mathrm{mg} /$ $\mathrm{ml}$ at $40^{\circ} \mathrm{C}$ after incubation for five days. Regardless temperatures, the mean average indicated that it-Achromobacter and Bacillus produced high enzyme quantities. Our results are in agreement with Nandimath et al. (2016) who reported that, both. Bacillus sp. and Pseudomonas sp. produced maximum cellulase production at $30^{\circ} \mathrm{C}$, the optimum reaction rate was observed at $30^{\circ} \mathrm{C}$. Also, Immanuel et al. (2006) mentioned that, the enzyme activity was carried out by using various temperature $20-50^{\circ} \mathrm{C}$. The enzyme activity was minimum at $20^{\circ} \mathrm{C}$ by the 
bacterial strains such as Cellulomonas, Bacillus and Micrococcus sp., respectively. Maximum production enzyme was reached at $40^{\circ} \mathrm{C}$, this results is approved with our result with Stenotrophomonas where it produced $(1.30 \mathrm{mg} / \mathrm{ml})$ at $40^{\circ} \mathrm{C}$. Further increase of temperature, reduced the enzyme activity considerably at $50^{\circ} \mathrm{C}$ by the tested bacterial strains. Shanmugapriya et al. (2012) mentioned that, optimized conditions of CMC and Coir waste as substrates for Bacillus sp. were at $40^{\circ} \mathrm{C}$.

Table (2): Effect of $p H$ on cellulase enzyme activity.

\begin{tabular}{|c|c|c|c|c|}
\hline \multirow{2}{*}{$\mathbf{p H}$} & \multicolumn{4}{|c|}{ Enzyme activity Units (mg/ml) } \\
\cline { 2 - 5 } & Achromobacter spanius & $\begin{array}{c}\text { Bacillus } \\
\text { amyloliquefaciens }\end{array}$ & $\begin{array}{c}\text { Stenotrophomonas } \\
\text { maltophilia }\end{array}$ & Mean \\
\hline 5.0 & 1.31 & 1.02 & 0.66 & 0.99 \\
\hline 5.5 & 1.31 & 1.07 & 0.80 & 1.06 \\
\hline 6.0 & 1.61 & 1.48 & 0.94 & 1.34 \\
\hline 6.5 & 1.48 & 1.41 & 1.28 & 1.39 \\
\hline 7.0 & 1.41 & 1.42 & 1.43 & 1.42 \\
\hline 7.5 & 1.37 & 1.30 & 1.31 & 1.33 \\
\hline 8.0 & 1.17 & 1.09 & 1.15 & 1.14 \\
\hline 8.5 & 1.13 & 0.95 & 0.89 & 0.99 \\
\hline 9.0 & 1.06 & 0.89 & 0.79 & 0.91 \\
\hline Mean & 1.70 & 1.52 & 1.11 & \\
\hline
\end{tabular}

L.S.D. at 0.05: Bacteria 0.017, pH 0.029, Bacteria x pH 0.051 .

Achromobacter and Bacillus showed the best result of cellulase production at pH 6 (1.61 and 1.48 $\mathrm{mg} / \mathrm{ml}$, respectively) while the best one for Stenotrophomonas was observed at $\mathrm{pH} 7(1.43 \mathrm{mg} / \mathrm{ml})$ (Table. 2). The mean average of $\mathrm{pH}$ values indicated that $\mathrm{pH} 6.5$ and $\mathrm{pH} 7$ were better in enzyme production for all isolates (1.39 and 1.42). Mean average of cellulase production showed the superiority of A. spanius and B. amyloliquefaciens over S. maltophilia. The enzymatic activity of Achromobacter and Bacillus was stable at $\mathrm{pH} 5.0$ and 5.5 then increased at $\mathrm{pH}$ 6.0. The results showed a decrease in enzyme activity at $\mathrm{pH}$ 9.0. On the other hand Stenotrophomonas was demonstrated the highest enzymatic activity at $\mathrm{pH} 7.0(1.43 \mathrm{mg} / \mathrm{ml})$ and showed progressive decrease until pH $9.0(0.79 \mathrm{mg} / \mathrm{ml})$. From the above results, it was found that, the best enzymatic activity of Achromobacter and Bacillus was at $\mathrm{pH} 6.0$ while the best enzymatic activity of Stenotrophomonas was at $\mathrm{pH}$ 7.0. Our results are in agreement with Ibrahim and El-diwany (2007) who mentioned that, the optimal production of cellulases at $\mathrm{pH} 7.5$ which is close to the optimum $\mathrm{pH}$ value of most Bacillus cellulases. Also, Immanuel et al. (2006) reported that, the endoglucanase enzyme activity by Cellulomonas $\mathrm{sp}$ at varying $\mathrm{pH}$ level showed that the activity was increased from $\mathrm{pH} 5.0$ to 7.0. Further increase in $\mathrm{pH}$ level to 8.0 and 9.0 resulted in considerable decrease in enzyme activity.

A. spanius and $B$. amyloliquefaciens produced 2.50 and $2.26 \mathrm{mg} / \mathrm{ml}$ at 6 days incubation period while S. maltophilia produced $1.43 \mathrm{mg} / \mathrm{ml}$ after 7 days of incubation (Table. 3). The lowest enzyme activity for cellulase produced by the isolated microorganisms was $1.44 \mathrm{mg} / \mathrm{ml}$ after 2 days incubation period. Also, cellulase enzyme activity on mean average basis was gradually increased with increasing the incubation period where the highest value detected after 6 days $(2.07 \mathrm{mg} / \mathrm{ml})$. According to mean average of isolates, it could be ranked as, $A$. Spanius $>$ B. amyloliquefaciens $>$ S. maltophilia. -The enzyme activity of Achromobacter, bacillus and Stenotroph- 
omonas were increased gradually with increased incubation periods our results are in agreement with Shaikh et al. (2013) who found that, increased cellulase production by Bacillus Sp. and Pseudomonas $S p$ fermentation was carried out at different incubation periods ranging from (2-5days), The incubation period of 4 days achieved the highest cellulase enzyme production on the other hand in our study the maximum production of enzyme activity was after incubation for 6 days $(2.5$ and $2.26 \mathrm{mg} / \mathrm{ml})$, respectively.

Table (3): Effect of incubation periods on cellulase enzyme activity.

\begin{tabular}{|c|c|c|c|c|}
\hline \multirow{2}{*}{$\begin{array}{c}\text { Incubation } \\
\text { period } \\
\text { (days) }\end{array}$} & \multicolumn{4}{|c|}{ Enzyme activity Units (mg/ml) } \\
\hline & $\begin{array}{c}\text { Achromobacter } \\
\text { spanius }\end{array}$ & $\begin{array}{c}\text { Bacillus } \\
\text { amyloliquefaciens }\end{array}$ & $\begin{array}{c}\text { Stenotrophomonas } \\
\text { maltophilia }\end{array}$ & Mean \\
\hline 2 & 1.62 & 1.61 & 1.08 & 1.44 \\
\hline 3 & 1.69 & 1.65 & 1.02 & 1.46 \\
\hline 4 & 1.92 & 1.72 & 1.23 & 1.63 \\
\hline 5 & 2.35 & 1.86 & 1.40 & 1.87 \\
\hline 6 & 2.50 & 2.26 & 1.44 & 2.07 \\
\hline 7 & 2.44 & 2.25 & 1.43 & 2.04 \\
\hline Mean & 1.79 & 1.62 & 1.09 & \\
\hline
\end{tabular}

L.S.D. at 0.05: Bacteria 0.021, Incubation periods 0.030, Bacteria $x$ Incubation periods 0.052.

Table (4): Effect of inoculum size on cellulase enzyme activity.

\begin{tabular}{|c|c|c|c|c|}
\hline \multirow{2}{*}{$\begin{array}{c}\text { Inoculum size } \\
\text { c.f.u/ml }\end{array}$} & Achromobacter spanius & $\begin{array}{c}\text { Eacillus } \\
\text { amyloliquefaciens }\end{array}$ & $\begin{array}{c}\text { Stenotrophomonas } \\
\text { maltophilia }\end{array}$ & Mean \\
\hline & 1.57 & 1.35 & 1.07 & 1.49 \\
\hline$\left(10^{-1}\right)$ & 2.51 & 1.83 & 1.79 & 1.91 \\
\hline$\left(10^{-3}\right)$ & 2.09 & 1.57 & 1.57 & 1.22 \\
\hline$\left(10^{-5}\right)$ & 1.98 & 1.43 & 1.39 & 1.14 \\
\hline$\left(10^{-6}\right)$ & 2.04 & 1.54 & 1.45 & \\
\hline Mean & & & & \\
\hline
\end{tabular}

L.S.D. at 0.05: Bacteria 0.037, Inoculum size 0.043, Bacteria x Inoculum size 0.075.

Inoculum size of $10^{-3}$ was the optimum inoculum for best growth of tested isolates to produce the best cellulase enzyme $(1.91 \mathrm{mg} / \mathrm{ml})$. In this regard, $A$. spanius produced the highest cellulase production $(2.51 \mathrm{mg} / \mathrm{ml})$ followed by B. amyloliquefaciens $(1.83 \mathrm{mg} / \mathrm{ml})$, then $S$. maltophilia $(1.79 \mathrm{mg} / \mathrm{ml})$ at inoculum size $10^{-3}$ (Table 4). Our results showed that the highest cellulase activity was resulted in inoculum size $10^{-3}$ for the three isolates. Shaikh $\boldsymbol{e t}$ al., (2013) mention that, the inoculum size of $2.0 \%$ achieved the highest cellulase enzyme production in Bacillus sp. 
Table (5): Effect of nitrogen sources on cellulase enzyme activity.

\begin{tabular}{|c|c|c|c|c|}
\hline \multirow{2}{*}{$\begin{array}{c}\text { Nitrogen } \\
\text { sources }\end{array}$} & Achromobacter spanius & $\begin{array}{c}\text { Eacillus } \\
\text { amyloliquefaciens }\end{array}$ & $\begin{array}{c}\text { Stenotrophomonas } \\
\text { maltophilia }\end{array}$ & Mean \\
\hline $\begin{array}{c}\text { Ammonium. } \\
\text { Sulphate }\end{array}$ & 1.44 & 1.29 & 1.19 & 1.31 \\
\hline Urea & 1.09 & 1.05 & 1.05 & 1.06 \\
\hline Yeast extract & 1.39 & 1.08 & 1.07 & 1.18 \\
\hline Mean & 1.31 & 1.14 & 1.10 & \\
\hline
\end{tabular}

L.S.D. at 0.05: Bacteria 0.031, Nitrogen Sources 0.032, Bacteria x Nitrogen Sources 0.057.

Ammonium sulphate was the best nitrogen source resulted in the highest enzymatic activity of cellulase for the three isolates $(1.31 \mathrm{mg} / \mathrm{ml})$ followed by yeast extract $(1.18 \mathrm{mg} / \mathrm{ml})$ then urea $(1.06 \mathrm{mg} /$ $\mathrm{ml}$ ) (Table.5). In this respect, A.spanius produced the highest cellulase activity $(1.44 \mathrm{mg} / \mathrm{ml})$, followed by B. amyloliquefaciens $(1.29 \mathrm{mg} / \mathrm{ml})$ and S.maltophilia $(1.19 \mathrm{mg} / \mathrm{ml})$ came to the next.-In general, ammonium sulphate and yeast extract as nitrogen source were used in the medium where produced the highest cellulase enzyme for Achromobacter (1.44 and $1.39 \mathrm{mg} / \mathrm{ml}$ ), respectively. On the other hand only ammonium sulphate was the best source of $\mathrm{N}$ to produce the maximum production of enzyme, at the same time urea and yeast extract did not effect on cellulase production by Bacillus and Stenotrophomonas isolates (Table. 5). Our results in the same line with Sethi et al. (2013), who mentioned that, among the various nitrogen sources tested, ammonium sulphate was found to be the best nitrogen source for cellulase production by Pseudomonas fuorescens, Bacillus subtilus, E. coli, and Serratia marscens due to their direct entry in protein synthesis.

The results in Table. (6) indicated that, $30 \mathrm{~g} / 1$ glucose, based on mean average, produced $2.09 \mathrm{mg} /$ $\mathrm{ml}$ better than $10 \mathrm{~g} / \mathrm{l}$ and $50 \mathrm{~g} / 1(1.95 \mathrm{mg} / \mathrm{ml})$. In the same way, $30 \mathrm{~g} / 1$ soluble starch produced $1.22 \mathrm{mg} /$ $\mathrm{ml}$ followed by $10 \mathrm{~g} / 1(1.17 \mathrm{mg} / \mathrm{ml})$ and $50 \mathrm{~g} / 1$ (1.03 $\mathrm{mg} / \mathrm{ml})$. While, S. maltophilia produced $0.94 \mathrm{mg} / \mathrm{ml}$ in case of $30 \mathrm{~g} / \mathrm{l}$ insoluble starch addition in (CMC) broth media instead of carboxymethyl cellulose. In- creasing the quantity of fructose up to $30 \mathrm{~g} / \mathrm{l}$ led the tested isolates to produce more enzyme which accounted for $1.23,1.12$ and $0.94 \mathrm{mg} / \mathrm{ml}$ for same sequence. In the same direction, increasing fructose up to $50 \mathrm{~g} / \mathrm{l}$ resulted in decrease in enzyme activity at of all isolates. Mean average of $\mathrm{C}$ source levels, 30 $\mathrm{g} / \mathrm{l}$ maltose produced $0.87 \mathrm{mg} / \mathrm{ml}$ followed by addition of $10 \mathrm{~g} / 1(0.86 \mathrm{mg} / \mathrm{ml})$ and $50 \mathrm{~g} / 1(0.85 \mathrm{mg} / \mathrm{ml})$. Addition of $30 \mathrm{~g} / 1$ maltose compensated 0.92, 0.81 and $0.85 \mathrm{mg} / \mathrm{ml}$ cellulose by A.spanius, B. amyloliquefaciens and S. maltophilia, respectively. Mean average of carbon sources reflected the superiority of $30 \mathrm{~g} / \mathrm{l}$ of sucrose $(0.94 \mathrm{mg} / \mathrm{ml})$ over $50(0.92 \mathrm{mg} /$ $\mathrm{ml})$ and $10 \mathrm{~g} / 1(0.89 \mathrm{mg} / \mathrm{ml})$. Comparison held between isolates indicted the superiority of $A$. spanius $(1.04 \mathrm{mg} / \mathrm{ml})$ over B. amyloliquefaciens $(0.89 \mathrm{mg} /$ $\mathrm{ml})$ and $S$. maltophilia $(0.81 \mathrm{mg} / \mathrm{ml})$ with addition of $30 \mathrm{~g} / \mathrm{l}$ of sucrose. The results indicated that, concentrations of glucose, soluble starch, insoluble starch, fructose, maltose and sucrose $(30 \mathrm{~g} / \mathrm{l})$ as a carbon source were better than $(10 \mathrm{~g} / \mathrm{l})$ and $(50 \mathrm{~g} / \mathrm{l})$, respectively in all the three isolates. Achromobacter was produced cellulase activity more than Bacillus and Stenotrophomonas with the use of all carbon sources and the highest production of cellulase enzyme was induced by glucose (30 g/l) as carbon source. Our results in the same line with Sethi et al. (2013), who mentioned that, glucose was found to be the best source for cellulase production. Also, the highest cellulase production compared to other carbon sources by Pseudomonas fluorescens, Bacillus subtilus, E. 
coli, and Serratia marscens. At the same time Shan- be the best carbon source for the substrates CMC and mugapriya et al. (2012) mentioned that, among the coir waste by Bacillus species, because glucose is various carbon sources tested, glucose was found to the good inducer of the cellulase production.

Table (6): Effect of carbon sources on cellulase enzyme activity.

\begin{tabular}{|c|c|c|c|c|c|}
\hline \multicolumn{6}{|c|}{ Enzyme activity (mg/ml) } \\
\hline $\begin{array}{l}\text { Carbon } \\
\text { source }\end{array}$ & $\begin{array}{l}\text { Quantity } \\
\text { by g/l }\end{array}$ & $\begin{array}{l}\text { Achromobacter } \\
\text { Spanius }\end{array}$ & $\begin{array}{c}\text { Bacillus } \\
\text { amyloliquefaciens }\end{array}$ & $\begin{array}{l}\text { Stenotrophomonas } \\
\text { Maltophilia }\end{array}$ & Mean \\
\hline \multirow{5}{*}{ Glucose } & 10 & 2.06 & 2.04 & 1.76 & 1.95 \\
\hline & 30 & 2.23 & 2.14 & 1.89 & 2.09 \\
\hline & 50 & 2.09 & 1.98 & 1.78 & 1.95 \\
\hline & Mean & 2.13 & 2.05 & 1.81 & \\
\hline & \multicolumn{2}{|c|}{ L.S.D. at 0.05} & \multicolumn{3}{|c|}{ Bacteria 0.032 , Glucose 0.030 , Bacteria $x$ Glucose 0.054} \\
\hline \multirow{5}{*}{$\begin{array}{l}\text { Soluble } \\
\text { starch }\end{array}$} & 10 & 1.23 & 1.18 & 1.10 & 1.17 \\
\hline & 30 & 1.27 & 1.24 & 1.14 & 1.22 \\
\hline & 50 & 1.05 & 0.96 & 1.07 & 1.03 \\
\hline & Mean & 1.18 & 1.13 & 1.10 & \\
\hline & \multicolumn{2}{|c|}{ L.S.D. at 0.05} & \multicolumn{3}{|c|}{$\begin{array}{c}\text { Bacteria } 0.031 \text {, Soluble starch } 0.031 \text {, Bacteria x Soluble } \\
\text { starch } 0.057\end{array}$} \\
\hline \multirow{5}{*}{$\begin{array}{l}\text { Insoluble } \\
\text { starch }\end{array}$} & 10 & 1.07 & 1.03 & 0.91 & 1.00 \\
\hline & 30 & 1.23 & 1.12 & 0.94 & 1.09 \\
\hline & 50 & 1.13 & 1.09 & 0.89 & 1.03 \\
\hline & Mean & 1.14 & 1.08 & 0.91 & \\
\hline & \multicolumn{2}{|c|}{ L.S.D. at 0.05} & \multicolumn{3}{|c|}{$\begin{array}{c}\text { Bacteria } 0.032 \text {, Insoluble starch } 0.031 \text {, Bacteria x } \\
\text { Insoluble starch } 0.055\end{array}$} \\
\hline \multirow{5}{*}{ Fructose } & 10 & 1.01 & 0.87 & 0.86 & 0.92 \\
\hline & 30 & 1.28 & 1.06 & 1.06 & 1.13 \\
\hline & 50 & 1.17 & 1.01 & 0.96 & 1.05 \\
\hline & Mean & 1.15 & 0.98 & 0.96 & \\
\hline & \multicolumn{2}{|c|}{ L.S.D. at 0.05} & \multicolumn{3}{|c|}{ Bacteria 0.03 , Fructose 0.04 , Bacteria $x$ Fructose 0.54} \\
\hline \multirow{5}{*}{ Maltose } & 10 & 0.92 & 0.79 & 0.89 & 0.86 \\
\hline & 30 & 0.93 & 0.85 & 0.83 & 0.87 \\
\hline & 50 & 0.92 & 0.81 & 0.83 & 0.85 \\
\hline & Mean & 0.92 & 0.81 & 0.85 & \\
\hline & \multicolumn{2}{|c|}{ L.S.D. at 0.05} & \multicolumn{3}{|c|}{ Bacteria 0.031 , Maltose 0.033 , Bacteria x Maltose 0.056} \\
\hline \multirow{5}{*}{ Sucrose } & 10 & 1.02 & 0.86 & 0.81 & 0.89 \\
\hline & 30 & 1.07 & 0.93 & 0.82 & 0.94 \\
\hline & 50 & 1.04 & 0.90 & 0.81 & 0.92 \\
\hline & Mean & 1.04 & 0.89 & 0.81 & \\
\hline & \multicolumn{2}{|c|}{ L.S.D. at0.05 } & \multicolumn{3}{|c|}{$\begin{array}{c}\text { Bacteria } 0.032 \text {, Sucrose } 0.030 \text {, Bacteria } \times \text { Sucrose } \\
0.054\end{array}$} \\
\hline
\end{tabular}


In conclusion, Achromobacter spanius was superior over Bacillus amyloliquefaciens and Stenotrophomonas maltophilia. This holds true with all carbon sources and the highest production of cellulase enzyme was induced by $30 \mathrm{~g} / 1$ glucose which considered the optimum level. Achromobacter spanius was superior over other isolates

\section{REFERENCES}

- Afzal, S.; Saleem, M.; Yasmin, R.; and Imran, M.N.M. (2010): Pre and post cloning characterization of a $b$-1, 4-endoglucanase from Bacillus sp. Mol. Biol. Rep., 37: 1717.

- Alam, M.Z.; Manchur, M.A. and Anwar, M.N. (2004): Isolation, purification, characterization of cellulolytic enzymes produced by the isolate Streptomyces omiyaensis. Pakistan J. Boil. Sci., 7(10): 1647.

- Ariffin, H.; Abdullah, N.; UmiKalsom, M.S.; Shirai, Y. and Hassan, M.A. (2006): Production and characterisation of cellulase by Bacillus pumilus EB3. International J. of Eng. and Technol., 3(1): 47.

- Assareh, R.; Zahiri, H.S.; Noghabi, K.A.; Aminzadeh, S. and Khaniki, B. (2012): Characterization of newly isolated Geobacillus sp. T1, the efficient cellulose producer on untreated barley and wheat straws. Bioresour: Technol., 120:99.

- Boom, R.; Sol, C. J. A.; Salimans, M. M. M.; Jansen, C. L. and Wertheim van-Dillen, P.M.E. (1990): Rapid and simple method for purification of nucleic acids. J. Clin. Microbiol. Mar., 495.

- Callow, N.; Ray, C.S.; Kelby, M.A. and Ju, L.K. (2016): Nutrient control for stationary phase cellulase production in Trichoderma reesei Rut C-30. Enzyme Microb. Technol., 82:8.

- Cao, L.; Qiu, Z.; You, J.; Tan, H. and Zhou, S. (2003): Isolation and characterization of entophytic streptomycete antagonists of fusarium wilt pathogen from surface sterilized banana roots. FEMS Microbiol. Lett., (247):147.
- Cirigliano, M.N.F.; Rezende, R.D.C.; Oliveira, M.N.G.; Pereira, P.H.F.; Nascimento, R.P.D.; Bon, E.P.D.S.; Macrae, A. and Coelho, R.R.R. (2013): Streptomyces misionensis PESB-25 produces athermoacidophilic endoglucanase using sugarcane bagasse and corn steep liquor as the sole organic substrates. Biomed Res. Int., From Bacillus sp. Mol. Biol. Rep., 37:1717.

- Gordon, A.S. and Weber, R.P. (1951): Colorimetric estimation of indole acetic acid. Plant Physiol., (26): 192.

- Hendricks, C.V.; Doyle, J.D; and Hugley, B. (1995): New solid medium for enumerating cellulose utilizing bacteria in soil. Appl. Environ. Microbiol., 61(5): 2016.

- Ibrahim, A.S.S and El-diwany, A.I. (2007): Isolation and Identification of New Cellulases Producing Thermophilic Bacteria from an Egyptian Hot Spring and Some Properties of the Crude Enzyme. Aust. J. Basic \& Appl. Sci., 1(4): 473.

- Immanuel, G.; Dhanusha, R.; Prema, P. and Palavesam, A. (2006): Effect of different growth parameters on endoglucanase enzyme activity by bacteria isolated from coir retting effluents of estuarine environment. Int. J. Environ. Sci. Tech., 3(1): 25.

- Lan, T.Q.; Wei, D.; Yang, S.T. and Liu, X. (2013): Enhanced cellulase production by Trichoderma viride in a rotating fibrous bed bioreactor. Bioresour. Technol. 133:175.

- Lee, Y.J.; Kim, B.K.; Lee, B.H.; Jo, K.I.; Lee, N.K.; Chung, C.H.; Lee, Y.C. and Lee, J.W. (2008): Purification and characterization of cellulase produced by Bacillus amyloliquefaciens DL-3 utilizing rice hull. Bioresour: Technol., 99(2):378.

- Lynd, L. R.; Weimer P.J.; Willem, H.; Van Zyl, W.H. and Pretorius, I.S. (2002): Microbial cellulose utilization: fundamentals \& biotechnology. Microbiol. Mol. Biol. Rev., 66: 506.

- Macedo, E.P.; Cerqueira, C.L.O.; Souza, D.A.J.; Bispo, A. S. R.; Coelho, R. R. R. and Nascimento, 
V. (2013): production of cellulose degrading enzyme on sisal and other agro-industrial residues using anew Brazilian Actinobacteria strain Streptomyces sp. SLBA-08, 30(4):729.

- Miller, G.L. (1959): Use of dinitrosalicilic acid as a reagent for the determination of reducing sugars. Anan. Chem., 31: 426.

- Nandimath, A.P.; Kharat, K.R.; Gupta, S.G. and Kharat, A.S. (2016): Optimization of cellulase production for Bacillus sp. and Pseudomonas sp. soil isolates. Afri. J. Microbiol. Res., 10(13): 410.

- Rastogi, A.; Bhalla, A.A.; Adhikari, A.A.; Kenneth, M.; Bischoff, B.; Stephen, R.; Hughes, B.; Lew, P.; Christopher, C.; Rajesh, K. and Sani, A. (2010): Characterization of thermostable cellulases produced by Bacillus and Geobacillus strains. Bioresour: Technol., 101: 8798.

- Romano, N.; Gioffre, A.; Sede, S. M.; Campos, E.; Cataldi, A. and Talia, P. (2013): Characterization of cellulolytic activities of environmental bacterial consortia from an Argentinian native forest. Curr. Microbiol., 67: 138.

- Saha, S.; Roy, R.; Sen, S.K. and Ray, A.K. (2006): Characterization of cellulase producing bacteria from the digestive tract of tilapia, Oreochromis mossambica (Peters) and grass carp, Ctenopharyngodon idella (Valenciennes). Aquaculture Res., 37: 380.

- Saini, R.; Saini, J.K.; Adsul, M.; Patel, A.K.; Mathur, A.; Tuli, D. and Singhania, R.R. (2015): Enhanced production by Penicillium oxalicum for bio-ethanol application. Bioresour. Technol., 188:240.

- Sarita, M.; Arora, A.; Singh, S. and Nain, L. (2013): Streptomyces griseorubens mediated delignification of paddy straw for improved enzymatic saccharification yields. Bioresour. Technol., 135:12.

- Shaikh, N.M.; Patel, A.A.; Mehta, S.A. and Patel, N.D.1. (2013): Isolation and Screening of Cellulolytic Bacteria Inhabiting Different Environment and
Optimization of Cellulase Production. Universal J. Environ. Res. \& Technol., 3(1): 39.

- Shanmugapriya, K.; Saravana, P.S.; Krishnapriya. A.; Manoharan, M.; Mythili, A. and Joseph, S. (2012): Isolation, Screening, and Partial Purification of Cellulase from Cellulase Producing Bacteria. International J. Advanc. Biotechnol. \& Res., 1: 509.

- Sharma, B.; Agarwal, R.; Singhania, R.R.; Satlewal, A.; Mathur, A.; Tuli, D. and Adsul, M. (2015): Untreated wheat straw: Potential source for diverse cellulolytic enzyme secretion by Penicillium janthinellum EMS-UV-8 mutant. Bioresour. Technol., 196:518.

- Sethi, S.; Datta, A.; Lal Gupta, B. and Gupta S. (2013): Optimization of Cellulase Production from Bacteria Isolated from Soil. Hindawi Publishing Corporation. ISRN Biotechnol. 1.

- Tamura, K.; Peterson, D.; Peterson, N.; Stecher, G.; Nei, M. and Kumar, S. (2011): MEGA5: Molecular Evolutionary I. N. Setia, Suharjono 548 Genetics Analysis Using Maximum Likelihood, Evolutionary Distance, and Maximum Parsimony Methods. Mol. Biol. Evol., 10: 2731.

- Techapun, C.; Poosaran, N.; Watanabe, M. and Sasaki, K. (2003): Optimization of aeration and agitation rates to improve cellulase-free xylanase production by thermo tolerant Streptomyces sp Ab106 and repeated fed-batch cultivation using agricultural waste. J. of Biosci. Bioeng., 4: 39.

- Vivek, K.; Sihag, R. C.; Sharma, R. C.; Gahlawat, S. K. and Gupta, R. K. (2008): Biodegradation of water hyacinth, sugarcane bagasse and rice husk through vermicomposting. Int. J. Environ. Waste Manag., 2: 601.

- Yin, L.J.; Huang, P.S. and Lin, H.H. (2010): Isolation of Cellulase Producing Bacteria and Characterization of the Cellulase from the Isolated Bacterium Cellulomonas Sp. J. Agric. Food Chem., 58: 9833. 
مجـلة

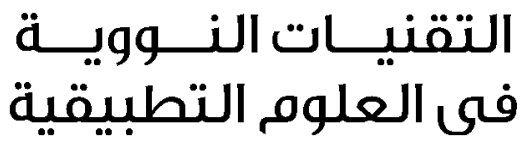

مجلد 6 ، عدد 1، ص ص 1 : 12 ، (2018)

الدراستة معمليتت لتمييز الظروف المثلى المؤثرة على انتاجيت السليوليز من البكتيريا

ممددو سالم الجملن'، اسماعيل ابوسريع الغندور'، اسامه عبد الباسط عبد العزيز"، عبير محمد موسي"،

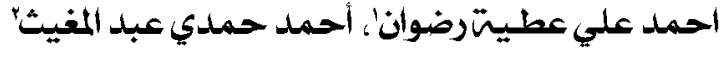

عزلت البكتريا الداخليت والتي انتجت اعلي قيهت لإنزيم السليوليز وهي اكروموباكتر سبانيس، باسيلس أميلوليكيفاسيانز وستينوتروفوموناس مالتوفيليا من الأوراق، السيقان

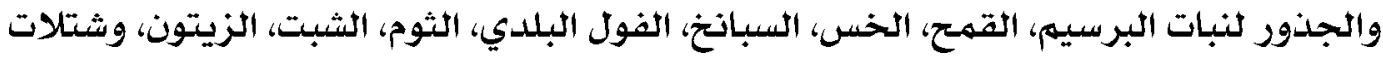
أشجار الأكاسيا والبروسوبس تمت الدراست تحت ظروف محكمتَ هِّ المعمل. أختبرت العوامل

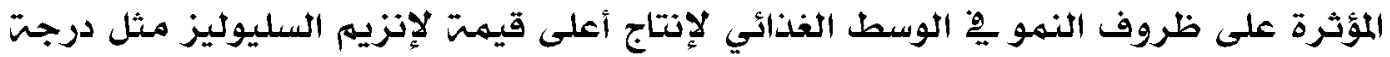
الحرارة، درجت الحموضت، فترة التحضين، حجم اللقاح، مصادر النيتروجين والكربون. أنتجت

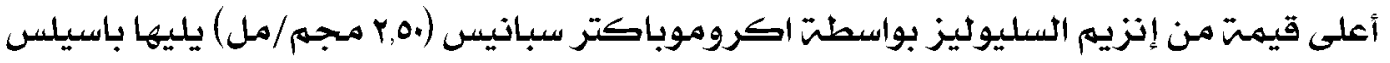

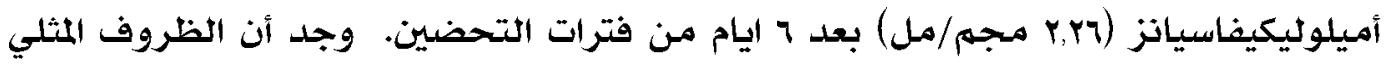

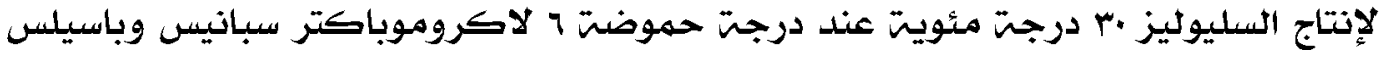

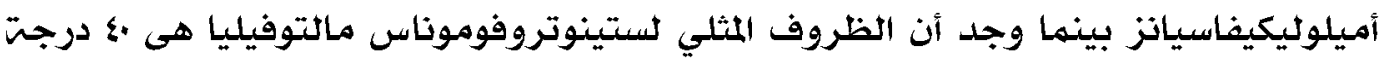

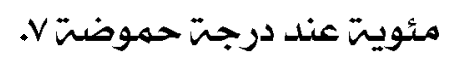

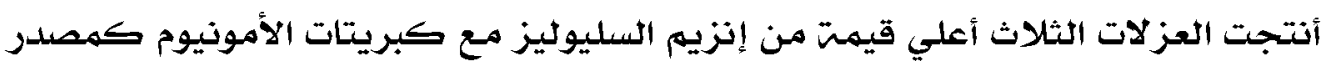

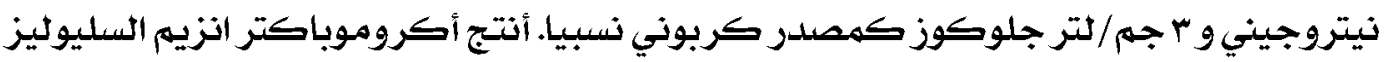

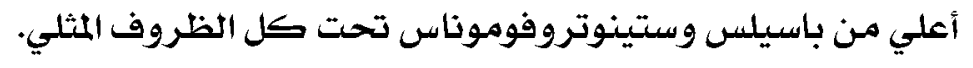

